\title{
The relationship between service quality, price perception, customer satisfaction and customer loyalty: A study in Nguoi Ban Vang - A pawn service company in Ho Chi Minh City
}

\author{
Vo Thi Quy ${ }^{1 *}$, Vo Duy Huy ${ }^{1}$ \\ ${ }^{1}$ International University - VNUHCM, Vietnam \\ *Corresponding author: vtquy@hcmiu.edu.vn
}

\begin{tabular}{|c|c|}
\hline ARTICLE INFO & ABSTRACT \\
\hline $\begin{array}{l}\text { DOI: } 10.46223 / \mathrm{HCMCOUJS} \text {. } \\
\text { econ.en.9.2.156.2019 }\end{array}$ & $\begin{array}{l}\text { This study aims to investigate the relationship between service } \\
\text { quality, price perception, customer satisfaction, and loyalty. The } \\
\text { survey method was applied with a sample size of } 350 \text { conducted } \\
\text { with Nguoi Ban Vang pawnshops located in Ho Chi Minh City. }\end{array}$ \\
\hline Received: June $27^{\text {th }}, 2019$ & The study results showed that service quality, price perception, and \\
\hline Revised: July $8^{\text {th }}, 2019$ & a new factor identified through the exploratory factor analysis, \\
\hline Accepted: July $15^{\text {th }}, 2019$ & $\begin{array}{l}\text { named staff competency, have a significant impact on customer } \\
\text { satisfaction at the significance } 0.05 \text { level. The research also found } \\
\text { that customer satisfaction impacts positively significantly on }\end{array}$ \\
\hline $\begin{array}{l}\text { Keywords: } \\
\text { customer loyalty, customer } \\
\text { satisfaction, Ho Chi Minh, } \\
\text { pawnshop, Vietnam }\end{array}$ & $\begin{array}{l}\text { customer loyalty at the } 0.01 \text { level. These results imply that } \\
\text { pawnshops should focus on increasing service quality, improving } \\
\text { pricing policies and staff competence in order to gain customer } \\
\text { satisfaction and their loyalty. }\end{array}$ \\
\hline
\end{tabular}

\section{Introduction}

After launching the "Renovation Scheme" in 1986, the trade openness of the Vietnamese economy remarkably increased and reached $200 \%$ according to the World Economy Report in 2018 through proactively integrated with the regional and global markets. Nowadays, the country has been recognized as one of the attractive countries for foreign direct investment flows in the Asia Pacific region. The regional and global integration of the economy has become the main driver of economic growth, beside unavoidable challenges as well as the increasing competitive pressures in the economy and the negative impacts of geopolitical troubles happening in the global economy.

Vietnamese economy had experienced deep depression from 2008 to 2013, due to the negative impact of the 2008 financial crisis originated in the U.S. From 2014 up to now the economy has recovered dramatically with the growth rate of GDP more than $6 \%$ on average. The manufacturing sector has witnessed a creation by a net 1.4 million jobs during the period from 2014 to 2017. The GDP growth rate of the Vietnamese economy was by 7.08 percent, the highest level over the last 11 years. Undeniably, the crucial contribution of the Vietnamese financial service system to the economic development, of which the role of commercial banks in providing short-term loans to small-medium enterprises and households, is significant. According to the report of the State Bank of Vietnam in the 2018 Vietnam Economic Forum, the 
bank credit accounted for around 130\% of Vietnam GDP; however, it does not meet the shortterm fund demand of the economy. As a result, the demand for credit service from nonbank institutions and other sources such as pawnshops and financial companies increases considerably.

Although Vietnamese small and medium enterprises (SME) contribute more than $40 \%$ GDP according to the General Statistics Office (GSO), they are hard to attain bank credit fully. In some cases, they have to seek the funding from informal credit granters, the so-called "black" credit. Even though the Vietnamese black credit market size cannot be known exactly, it is believed that its size is larger than the formal credit market many times. Black credit providers have been criticized for charging high-interest rate, and their illegal actions used to claim their funds. In such cases, using pawn services seems to be a good alternative. According to the recent survey of Forbes Vietnam, there are more than 2200 pawn shops across the country, an impressive number, however, the quality of their services is still questionable.

Pawnshop operations are regulated by Decree No. 96/2016/ND-CP dated July 01, 2016. Under the regulation, pawn service, defined as one type of legal credit service which requires borrowers to deposit their properties as collaterals in the pawnshop, however, does not require a feasible business plan to prove for their meeting debtobligation. Specifically, the Decree states that customers who are able to access pawn services must be 18 years old or above, legitimate citizens, and possess lawful properties as collaterals for loan security. Clearly, the legal regulations applied to pawnshop services are much simpler than those applied to commercial banks.

Ho Chi Minh City, the biggest city and the center of trade and technology of Vietnam with population of around 13 million people and GDP growth rate of more than $9 \%$, is a potential market with a huge demand for pawnshop services. To catch the opportunity, the pawnshop named Nguoi Ban Vang (NBV) has been established for nearly 2 years since 2017 November. At the present, Nguoi Ban Vang has successfully opened 11 pawnshops in Ho Chi Minh City and Binh Duong Province, with approximately 1.500 customers. It intends to expand its pawnshop network in Ho Chi Minh City and the Southeast and Mekong Delta area soon, therefore customers' satisfaction and loyalty have become the main concern of NBV management. This is the reason why this study is conducted to investigate the relationship between pawnshop service quality of NBV, its customer satisfaction and loyalty. The study also tests the relationship between price perception and customer satisfaction because customers of this service are really sensitive to price, according to preliminary research conducted by NBV research team. The rest of the paper is structured into four sections, literature review, data collection, and processing, finding discussion and recommendations.

\section{Literature review}

\subsection{Service quality}

In the beginning, extensive research of service quality was carried out by (Parasuraman, Zeithaml, \& Berry, 1985), which initially led to the identification of ten criteria in the assessment of service quality. Subsequently, the initial criteria were, on purpose, merged into 
five dimensions in the research of (Zeithaml, Parasuraman, \& Berry, 1990) as follows:

Reliability can be defined as the competence in which service firms are empowered to execute the service they commit in a trustful and precise manner. Generally, and comprehensively understanding, reliability covers all the promises committed by the firms in delivery terms, problem settlement and pricing policies. Therefore, it would be very comfortable for clients who maintained their business linkages with those firms which are able to keep promises. Promising and keeping them are the crucial facet in the service quality which customers perceive and express their loyalty to the firms. As a result, the service firms must watch out for their customers' aspirations about the dimension of reliability. Regarding pawn service, the reliability dimension may cover the promise to perform transactions at a predefined contract term of the loan, such as interest rate and the fee charged or informing customers on a timely basis about the upcoming changes in the interest and fee quotation, terms of the loans.

Besides, it can be also related to the attitude of the staff in trying to solve their customer's problems.

Responsiveness can be defined as the service quality dimension which deals with the willingness to support clients and to perform express services. This dimension focuses on the staff's attitude and promptness in dealing with customer requests, questions, and complaints, as well as on punctuality, physical availability, and professional commitment. The dimension can be measured based on the lead time needed to fulfill service delivery. The level of responsiveness to customers can be enhanced by continuously keeping an eye on the process of service delivery and employees' attitude towards their customers' requests. In the pawn service, this dimension can cover a wide range of things such as the willingness and availability of the staff in performing a transaction with customers. In this sense, NBV staff is expected to act in a prompt, confident and professional manner as serving their customers.

Assurance is defined as the manner of elegance and cordiality that employees show up to customers and the ability of service firms and their employees to implant trust and assurance in their customers. This dimension is critically important in financial services because of trust and credibility. For pawn service, the dimensions of assurance can be reassuring customers if they are worried about their assets stored in the pawnshop, explaining and advising customers in a courteous manner. The staffs of pawn shops have to show to customers the sealing process applied for any assets.

Tangible is the dimension that covers the presence of physical facilities, equipment, communication tools and information technology, which all direct customers to the service quality offered. This dimension builds the firm image in customers' eyes. For pawnshops, this dimension can be counted as the facilities and equipment installed at the store as well as the store's decoration to attract customers such as banners/posters which convey information that customers need like the pawn asset portfolio, the interest, and fee, etc.

Empathy is defined as the dedicated attentiveness and customized attention that every employee of a service firm reserves to customers. In this dimension, the service provider tries to prove to customers that they are unique and very special and deserved to have the full 
attentiveness and individualized caring from the service firm's employees. Service providers need to be thoroughly aware of their customers' needs and expectations as well as preferences of choice or alternatives. Specifically, in the pawn service, this dimension can be attributed to the customized way of the staff to serve each individual customer, i.e., showing dedicated care to customers, making and maintaining a warm and friendly conversation with their customers.

\subsection{Price perception/consciousness}

It can be defined as the procedure by which clients figure out and analyze the charged price and the perceived value to services or products. Price perception and its relationship with other business concepts have been the prominent focus and interest of scholars for many decades. Price perception involves many critical dimensions reflected in the literature review; three dimensions of the concept will be discussed in this study as follows:

\section{Price perception}

This refers to how customers perceive quality associated with the price of services or products. Price, as universally agreed, is the effective index to quality perception. Customers believe that high-priced products/services are directly linked to high quality, which indicates that price give hints and clues to quality. Many customers would consider price is a good parameter of product/service quality (Estelami \& De Maeyer, 2004; Zhou, Su, \& Bao, 2002). Customers also give a more favorable assessment of quality when the price goes up (Alford \& Biswas, 2002; Erdem, Swait, \& Louviere, 2002).

\section{Price consciousness}

Price consciousness is defined as the degree to which the consumer focuses exclusively on paying a low price (Lichtenstein, Ridgway, \& Netemeyer, 1993). Price consciousness can be considered as an attitude of each individual customer regarding the sum of money they pay out (Sinha \& Batra, 1999). Those customers who are exposed to high price consciousness are likely to make more price comparisons (Alford \& Biswas, 2002). Economists have apparently demonstrated that price really plays a key role in customers' options to make purchases. They also proposed that buyers already had adequate and precise information about service charges. In addition, the price also has a more significant and impulsive role in their buying process (Monroe, 1973). For pawn service, the interest rate of the loan is the service price. The higher the price consciousness is, the lower the service is used.

\subsection{The relationship between service quality, price perception, customer satisfaction, and customer loyalty}

Parasuraman et al. (1985) defined service quality as "the delivery of excellent or superior service relative to customer expectation". Ehsani and Ehsani (2015) concluded that service quality is the customer's perception of the overall quality or superiority of the service for its intended use in comparison with other alternatives. Delivering the best quality service would help businesses gain competitive advantages over other players in the industry (Rivers \& Glover, 2008). Service quality cannot be assessed from the viewpoint of the service providers; it must be assessed from the customer's perspective. Thus, the quality of goods and/or services 
relies on the company ability to meet customer's expectations.

According to Bei and Chiao (2001), service quality and price relationship is the foundation built towards customer satisfaction, which is more diverse and expansive than the perception that service quality is the critical determinant of customer satisfaction (Islam, Khadem, \& Sayem, 2012). Price can be treated as a resource to increase both profit and customer satisfaction (Ehsani \& Ehsani, 2015). Malik, Ghafoor, and Hafiz (2012) stated that price affects customer satisfaction. The similar statement can be found in researches of Jahanshahi, Gashti, Mirdamadi, Nawaser, and Khaksar (2011), Sadeghi and Heidarzadeh (2010), Tu, Li, and Chih (2013).

The satisfaction of provided goods and services creates specific levels of perceived value for the customer so that the customer remains positively engagement with the organization (Wicks \& Roethlein, 2009). Oliver (1999) conceptualized customer satisfaction as a customer's fulfillment response: a judgment that a product or service provides a pleasurable level of consumption-related fulfillment. Bendall-Lyon and Powers (2004) suggested that customer satisfaction is the customer's reaction to the perceived difference between performance appraisal and expectations. Others suggested that customer satisfaction is the function of expectation, performance and disconfirmation (Churchill \& Surprenant, 1982; McQuitty, Finn, \& Wiley, 2000; Wirtz \& Bateson, 1999; Woodruff, Cadotte, \& Jenkins, 1983). Others stated that customer satisfaction is a post-choice evaluative judgment concerning a purchase selection (Westbrook \& Oliver, 1991).

According to Philip Kotler, customer satisfaction is the feeling of a customer originating from a comparison between what he or she receives from consuming products/services with their own expectation (Kotler, Bowen, \& Makens, 2013). The level of satisfaction depends on the difference between the outcome and the expectation. If what customers get is lower than what they really expected, then they will be unhappy, or unsatisfied. The opposite situation is applied, when customers receive more than what they really expected, they will be satisfied. In another point of view, customer satisfaction is the comprehensive attitude of customers towards a specific supplier of products or services, or an emotion responding to the difference between what they forecast and what they really receive, in terms of some specific need, target or aspiration (Hansemark \& Albinsson, 2004).

Customer loyalty can be defined as both the repeat purchases from the same service firms as well as the individual attitude of customers towards the firms (Day, 1976). From another viewpoint, customer loyalty was defined as the traits of customers who bought products or services from a single firm without any searching for information about it (Newman \& Werbel, 1973). Nevertheless, this was not reasonable because true loyalty could be existent even though the customer knew about different information on the firm's competitor's products or services (Oliver, 1999).

Singh and Khan (2012) defined customer loyalty as the proactiveness and availability of customers to make purchases at one supplying firm over other competitors in the market. Loyalty is the result of past comfortable and satisfying experience with the services, which they 
return to continue to use the service or buy the product without comparing with other substitutes regarding service terms, price or configuration of the service/product (Ghavami \& Olyaei, 2006; Zikmund, 2003). Customer loyalty was also given the definition which was viewed as the attitude towards the loyalty of a specific brand name and repeat patronage behavior (East, Hammond, \& Lomax, 2008).

Customer loyalty is also described as frequently repurchase, retention with the brand, price indifference, opposition to competitor's persuasion and positive word-of-mouth (Ganesh, Arnold, \& Reynolds, 2000). Similarly, it suggests that voluntary and available willingness to convey good words about a specific service firm as well as repurchase actions among the most critical components of customer loyalty (Dwyer, Schurr, \& Oh, 1987; Fornell, 1992). A series of research works shared the same similarity such as those conducted by (Sirdeshmukh, Singh, \& Sabol, 2002; Zeithmal, Berry, \& Parasuraman, 1996).

However, customer loyalty symbolized itself in not only a behavioral manner but also in attitude in thought.

Based on the literature review and research objectives mentioned above, the two research models and three research hypotheses were proposed as below:

Model 1: $f($ customer satisfaction $)=\beta 0+\beta 1($ service quality $)+\beta 2$ (Price Perception $)+\varepsilon i$

Model 2: $\mathrm{f}($ customer loyalty $)=\beta 0+\beta 1$ (service quality $)+\varepsilon \mathrm{i}$

\section{Data collection and processing}

\subsection{Data collection}

The data was collected by using survey questionnaire. There were two phases of collecting data from customers: pilot and final. In the pilot phase, the questionnaire was sent to 50 customers with the help of the front-end service tellers of Nguoi Ban Vang at the pawn stores. Two techniques were used to collect data (i) Clearly explain the purpose of the survey and politely ask customers to complete the questionnaire as they come to make the transaction at Nguoi Ban Vang pawn service stores; and (ii) Make a phone call and interview customers and have the questionnaire filled by the respondents. For the official survey, the same techniques were applied as well.

The purpose to do the pilot test is to revise measurement scales and research models. Through the pilot test, 21 items in measurement scales were eliminated due to loading factor lower than .5. or items loaded on more than one factor with a similar loading factor. The pilot test resulted in 3 factors that could impact customer satisfaction. They are service quality, price perception, and a new factor with three items grouped together. These items refer to the competency of the staff, therefore, the new variable was named Staff competency.

In the concept of service quality proposed by Zeithaml et al. (1990), there was no clear dimension that is directly related to staff. Instead, the characteristics of the staff were put into dimensions of reliability, assurance, empathy as well as responsiveness. Moreover, there are many other factors that affect customer satisfaction, which may include friendly staff, courteous staff, knowledgeable staff, helpful staff (Hokanson, 1995). More specifically, in pawn service, 
staff competence is crucial because most of the time, customers interact with the front-end staff, which can affect their satisfaction. Therefore, a new hypothesis was added.

Base on the proposed research models and the results of exploratory factor analysis, four research hypotheses were proposed as below:

H1: Service quality has positive effect on customer satisfaction

H2: Price perception has positive effect on customer satisfaction

H3: Customer satisfaction has positive effect on customer loyalty

H4: The positive impact of staff competency on customer satisfaction

Based on the result of the pilot test, the final survey questionnaire was revised as reflected in the pilot test outcomes. The official survey was conducted with a convenience sampling technique and on the sample size of 350 respondents, of which 57 percent is female and the rest is male; nearly 65 percent is under 40 years old; approximately 70 percent of the sample has monthly income under 20 million VNĐ.

\subsection{EFA and reliability test}

Exploratory factor analysis (EFA) was undertaken to identify constructs under each research concept, and items with loadings higher than 0.5. The test resulted in three factors named Service Quality, Staff Competence, and Price Perception with Cronbach's Alpha value presented in Table 1 below. The Kaiser-Meyer-Olkin (KMO) measure of sampling adequacy had a value of 0.877 while Bartlett's test was significant $(\mathrm{Sig}=.000)$ indicating that the data is suitable for factor analysis. Three factors with eigenvalues greater than one were extracted and the total variance explained of 59.07\%, and no item was dropped due to low factor loadings.

\section{Table 1}

Reliability test for independent variables

\begin{tabular}{|c|l|c|c|}
\hline No. & Factors & Number of items & Cronbach's Alpha (N=351) \\
\hline 1 & Service Quality & 6 & .812 \\
\hline 2 & Staff Competence & 3 & .768 \\
\hline 3 & Price Perception & 4 & .747 \\
\hline $\begin{array}{l}\text { *All items have factor loadings } \geq .5 \\
\text { KMO index }=.877 \text { and Sig. of Bartlett's test }=.000 \\
\text { Total variance explained }=\mathbf{5 9 . 0 7 \%}\end{array}$ \\
\hline
\end{tabular}

Source: Data analysis result of the research

The same technique was applied to the two other research concepts, customer satisfaction and loyalty. The results are presented in Table 2 and Table 3 as below: 


\section{Table 2}

Reliability test for customer satisfaction

\begin{tabular}{|l|l|c|c|}
\hline No. & Factor & $\begin{array}{c}\text { Number of } \\
\text { items }\end{array}$ & $\begin{array}{c}\text { Cronbach's Alpha } \\
(\mathbf{N = 3 5 1 )}\end{array}$ \\
\hline 1 & Customer Satisfaction & 3 & .664 \\
\hline $\begin{array}{l}* \text { All items have factor loadings } \geq .5 \\
\text { KMO index }=.658 \text { and Sig. of Bartlett's test }=.000 \\
\text { Total variance explained }=\mathbf{6 0 . 4 4 \%}\end{array}$
\end{tabular}

Source: Data analysis result of the research

\section{Table 3}

Reliability test for customer loyalty

\begin{tabular}{|l|l|c|c|}
\hline No. & Factors & $\begin{array}{c}\text { Number of } \\
\text { items }\end{array}$ & $\begin{array}{c}\text { Cronbach's Alpha } \\
(\mathbf{N = 3 5 1 )}\end{array}$ \\
\hline 1 & Customer Loyalty & 3 & .819 \\
\hline$*$ All items have factor loadings $\geq .5$ & \\
KMO index $=.627$ and Sig. of Bartlett's test $=.000$ \\
Total variance explained $=\mathbf{7 3 . 4 1 \%}$
\end{tabular}

Source: Data analysis result of the research

\subsection{Correlation test}

The test was conducted to test the correlation between variables in the research model and the existence of autocorrelation phenomenon. The test results that all variables in the research model are correlated at the significance level of 1\% (2-tailed), and there is no autocorrelation phenomenon.

\section{Table 4}

Correlation Matrix

\begin{tabular}{|c|c|c|c|c|c|}
\hline & SQ & PP & SC & CS & CL \\
\hline SQ & 1 & & & & \\
\hline PP & $.592 * *$ & 1 & & & \\
\hline SC & $.454 * *$ & $.500 * *$ & 1 & & \\
\hline CS & $.606 * *$ & $.584 * *$ & $.656^{* *}$ & 1 & \\
\hline CL & $.582 * *$ & $.652 * *$ & $.513 * *$ & $.577 * *$ & 1 \\
\hline
\end{tabular}

Note: **. Correlation is significant at the 0.01 level (2-tailed).

Source: Data analysis result of the research 


\section{Testing research model by using SEM linear structure model}

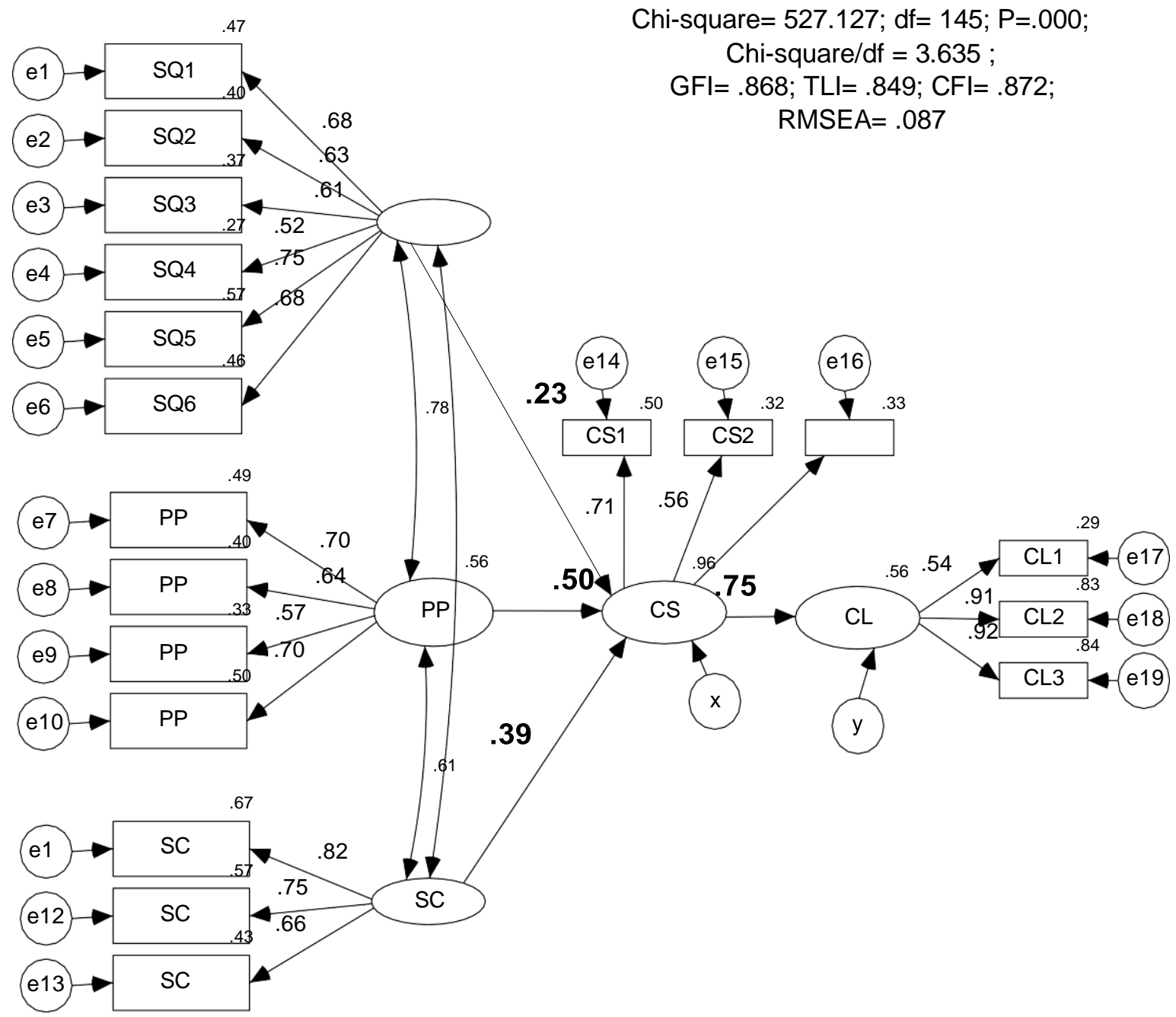

Figure 1. Structural model (Standardized estimates)

The estimated results (standardized) of the research model of SEM linear structural analysis showed that the model with Chi-square (chi-square) $=527.127$; degrees of freedom $(\mathrm{df})=145 ; \mathrm{P}$-value $=, 000 ; \mathrm{CMIN} / \mathrm{df}=3,635$; GFI (goodness of fix index $)=0.868>0.8$; TLI (Tucker - Lewis index $)=0.849$; CFI $($ Comparative Fit Index $)=0.872$ are greater than 0.8 ; RMSEA (Root Mean Square Error) $=0.087$ indicates the research model suitable for market data (see Figure 1. above for details).

\section{Testing research hypotheses with SEM linear structure model}

The results of the study model estimation in linear structure analysis (SEM) show that the hypothetical relationship in the research model is statistically significant because of the values of $\mathrm{P}=0,000$, less than 0,05 ; reach the required level at $95 \%$ confidence level (see Table 5 for details). 


\section{Finding discussion and recommendations}

The research results illustrate that service quality, staff competence, and price perception have significant positive relationships with customer satisfaction, and then customer satisfaction has a significant relationship with customer loyalty. For pawn service, customers behave similarly to those of bank or finance company's clients in the sense that they really care for the service quality, staff competence, and service interest and fee.

At NBV case, customers are fully aware of the interest and fee charged on them as doing pawn service transactions. NBV staff always advised customers clearly and honestly each term and condition of the pawn service contract so that they can release with possible complaints in the next transactions. The staff is also the key element in enhancing customer satisfaction, which was proven by these research results. The staff in the pawn service should really take a wellrounded training program so that they can perform professionally in front of customers.

In terms of pricing policy, Nguoi Ban Vang Company should consider carefully about the interest and fee charged on customers because the research points out that customers are quite sensitive to price. Not only are the pricing policies published and made transparent to customers, they also need to be notified of changes. Moreover, they really appreciate more competitive pricing than other competitors. With Nguoi Ban Vang, it is a breakthrough that pre-collection is not applied, as well as the re-calculation of interest and fee charged when customers make a redemption. It is believed that these competitive edges over other competitors should be reinforced and take more effect in the future, making them one of the key features in marketing activities. As proven in other previous studies, customer loyalty can be acquired from customer satisfaction. The higher level of satisfaction customers experiences with the firm, the more likely they become loyal to the firm. The cost of acquiring new customers is much higher than the cost of retaining one. Therefore, trying to achieve customer loyalty and expand the base of loyal customers will reassure the sustainability and higher profitability for firms. This suggests that pawnshop should not look at the unethical benefit from frauding customers by replacing their assets with low-quality ones because customers will be more reluctant and uncomfortable to do a pawn transaction. Therefore, Nguoi Ban Vang should focus on improving service quality to gain more customer satisfaction, which leads to enhanced customer loyalty.

\section{References}

Alford, B. L., \& Biswas, A. (2002). The effects of discount level, price consciousness and sale proneness on consumers' price perception and behavioral intention. Journal of Business Research, 55(9), 775-783. doi:10.1016/S0148-2963(00)00214-9

Angur, M. G., Nataraajan, R., \& Jahera, J. S. (1999). Service quality in the banking industry: An assessment in a developing economy. International Journal of Bank Marketing, 17(3), 116-125. doi:10.1108/02652329910269211

Bei, L.-T., \& Chiao, Y.-C. (2001). An integrated model for the effects of perceived product, perceived service quality, and perceived price fairness on consumer satisfaction and 
loyalty. Journal of Consumer Satisfaction, Dissatisfaction and Complaining Behavior, 14(2), 25-40.

Bendall-Lyon, D., \& Powers, T. L. (2004). The impact of structure and process attributes on satisfaction and behavioral intentions. Journal of Services Marketing, 18(2), 114-121. doi:10.1108/08876040410528719

Churchill, G. A., Jr., \& Surprenant, C. (1982). An investigation into the determinants of customer satisfaction. Journal of Marketing Research, 19(4), 491-504. doi:10.2307/3151722

Day, G. S. (1976). A two-dimensional concept of brand loyalty. In M. Beckmann \& H. P. Künzi (Eds.), Mathematical Models in Marketing (pp. 89-89). Berlin, Heidelberg: Springer. doi:10.1007/978-3-642-51565-1_26

Dodds, W. B., \& Monroe, K. B. (1985). The effect of brand and price information on subjective product evaluations. Advances in Consumer Research, 12(1), 85-90. Retrieved March 20, 2019, from https://www.acrwebsite.org/volumes/6364/volumes/v12/NA-12

Dwyer, F. R., Schurr, P. H., \& Oh, S. (1987). Developing buyer-seller relationships. Journal of Marketing, 51(2), 11. doi:10.2307/1251126

East, R., Hammond, K., \& Lomax, W. (2008). Measuring the impact of positive and negative word of mouth on brand purchase probability. International Journal of Research in Marketing, 25(3), 215-224. doi:10.1016/j.ijresmar.2008.04.001

Ehsani, Z., \& Ehsani, M. H. (2015). Effect of quality and price on customer satisfaction and commitment in Iran auto industry. International Journal of Service Science, Management and Engineering, 1(5), 52-56. Retrieved March 21, 2019, from http://www.openscienceonline.com/journal/archive2?journalId=729\&paperId=1384

Erdem, T., Swait, J., \& Louviere, J. (2002). The impact of brand credibility on consumer price sensitivity. International Journal of Research in Marketing, 19(1), 1-19. doi:10.1016/S0167-8116(01)00048-9

Estelami, H., \& De Maeyer, P. (2004). Product category determinants of price knowledge for durable consumer goods. Journal of Retailing, 80(2), 129-137. doi:10.1016/j.jretai.2004.04.003

Fornell, C. (1992). A national customer satisfaction barometer: The Swedish experience. Journal of Marketing, 56(1), 6-21. doi:10.2307/1252129

Ganesh, J., Arnold, M. J., \& Reynolds, K. E. (2000). Understanding the customer base of service providers: An examination of the differences between switchers and stayers. Journal of Marketing, 64(3), 65-87. doi:10.1509/jmkg.64.3.65.18028

Ghavami, A., \& Olyaei, A. (2006). The impact of CRM on customer retention (Unpublished master's thesis). Lulea University of Technology, Luleå, Sweden.

Grewal, D., Krishnan, R., Baker, J., \& Borin, N. (1998). The effect of store name, brand name and price discounts on consumers' evaluations and purchase intentions. Journal of Retailing, 74(3), 331-352. doi:10.1016/S0022-4359(99)80099-2 
Hansemark, O. C., \& Albinsson, M. (2004). Customer satisfaction and retention: The experiences of individual employees. Managing Service Quality: An International Journal, 14(1), 4057. doi:10.1108/09604520410513668

Hokanson, S. (1995). The deeper you analyze, the more you satisfy customers. Marketing News, 29(1), 16-16.

Islam, M. A., Khadem, M., \& Sayem, A. (2012). Service quality, customer satisfaction and customer loyalty analysis in Bangladesh apparel fashion retail: An empirical study. International Journal of Fashion Design, Technology and Education, 5(3), 213-224. doi:10.1080/17543266.2012.723754

Jahanshahi, A. A., Gashti, M. A. H., Mirdamadi, S. A., Nawaser, K., \& Khaksar, S. M. S. (2011). Study the effects of customer service and product quality on customer satisfaction and loyalty. International Journal of Humanities and Social Science, 1(7), 253-260.

Kotler, P., Bowen, J., \& Makens, J. (2013). Marketing for hospitality and tourism (5th ed.). Upper Saddle River, NJ: Pearson Higher Education, Inc.

Lichtenstein, D. R., Ridgway, N. M., \& Netemeyer, R. G. (1993). Price perceptions and consumer shopping behavior: A field study. Journal of Marketing Research, 30(2), 234245. doi:10.1177/002224379303000208

Malik, M. E., Ghafoor, M. M., \& Hafiz, K. I. (2012). Impact of brand image, service quality and price on customer satisfaction in Pakistan telecommunication sector. International Journal of Business and Social Science, 3(23), 123-139.

McGowan, K. M., \& Sternquist, B. J. (1998). Dimensions of price as a marketing universal: A comparison of Japanese and US consumers. Journal of International Marketing, 6(4), 4965. doi:10.1177/1069031X9800600408

McQuitty, S., Finn, A., \& Wiley, J. B. (2000). Systematically varying consumer satisfaction and its implications for product choice. Academy of Marketing Science Review, 10(1), 116.

Monroe, K. B. (1973). Buyers' subjective perceptions of price. Journal of Marketing Research, 10(1), 70-80. doi:10.1177/002224377301000110

Newman, J. W., \& Werbel, R. A. (1973). Multivariate analysis of brand loyalty for major household appliances. Journal of Marketing Research, 10(4), 404-409. doi:10.1177/002224377301000408

Oliver, R. L. (1999). Whence consumer loyalty? Journal of Marketing, 63(4), 33-44. doi:10.1177/00222429990634s105

Parasuraman, A., Zeithaml, V. A., \& Berry, L. L. (1985). A conceptual model of service quality and its implications for future research. Journal of Marketing, 49(4), 41-50.

Rivers, P. A., \& Glover, S. H. (2008). Health care competition, strategic mission, and patient satisfaction: Research model and propositions. Journal of Health Organization and Management, 22(6), 627-641. doi:10.1108/14777260810916597

Sadeghi, T., \& Heidarzadeh, H. K. (2010). Customer satisfaction factors (CSFs) with online banking services in an Islamic country: I.R. Iran. Journal of Islamic Marketing, 1(3), 249267. doi:10.1108/17590831011082428 
Singh, R., \& Khan, I. A. (2012). An approach to increase customer retention and loyalty in B2C World. International Journal of Scientific and Research Publications, 2(11), 1-5.

Sinha, I., \& Batra, R. (1999). The effect of consumer price consciousness on private label purchase. International Journal of Research in Marketing, 16(3), 237-251. doi:10.1016/S0167-8116(99)00013-0

Sirdeshmukh, D., Singh, J., \& Sabol, B. (2002). Consumer trust, value, and loyalty in relational exchanges. Journal of Marketing, 66(1), 15-37. doi:10.1509/jmkg.66.1.15.18449

Tu, Y.-T., Li, M.-L., \& Chih, H.-C. (2013). An empirical study of corporate brand image, customer perceived value and satisfaction on loyalty in shoe industry. Journal of Economics and Behavioral Studies, 5(7), 469-483. doi:10.22610/jebs.v5i7.421

Westbrook, R. A., \& Oliver, R. L. (1991). The dimensionality of consumption emotion patterns and consumer satisfaction. Journal of Consumer Research, 18(1), 84-91. doi: $10.1086 / 209243$

Wicks, A. M., \& Roethlein, C. J. (2009). A satisfaction-based definition of quality. The Journal of Business and Economic Studies, 15(1), 82-97. Retrieved March 22, 2019, from: https://www.econbiz.de/Record/a-satisfaction-based-definition-of-quality-wicksangela/10003860206

Wirtz, J., \& Bateson, J. E. (1999). Consumer satisfaction with services: Integrating the environment perspective in services marketing into the traditional disconfirmation paradigm. Journal of Business Research, 44(1), 55-66. doi:10.1016/S01482963(97)00178-1

Woodruff, R. B., Cadotte, E. R., \& Jenkins, R. L. (1983). Modeling consumer satisfaction processes using experience-based norms. Journal of Marketing Research, 20(3), 296304. doi: $10.2307 / 3151833$

Zeithaml, V. A. (1988). Consumer perceptions of price, quality, and value: A means-end model and synthesis of evidence. Journal of Marketing, 52(3), 2-22. doi: 10.2307/1251446

Zeithaml, V. A., Parasuraman, A., \& Berry, L. L. (1990). Delivering quality service: Balancing customer perceptions and expectations. New York, NY: Simon and Schuster.

Zeithaml, V. A., Berry, L. L., \& Parasuraman, A. (1996). The behavioral consequences of service quality. Journal of Marketing, 60(2), 31-46. doi:10.2307/1251929

Zhou, K. Z., Su, C., \& Bao, Y. (2002). A paradox of price-quality and market efficiency: A comparative study of the US and China markets. International Journal of Research in Marketing, 19(4), 349-365. doi:10.1016/S0167-8116(02)00096-4

Zikmund, W. G. (2003). Business Research Methods. Mason, OH: Thomson/South-Western. 